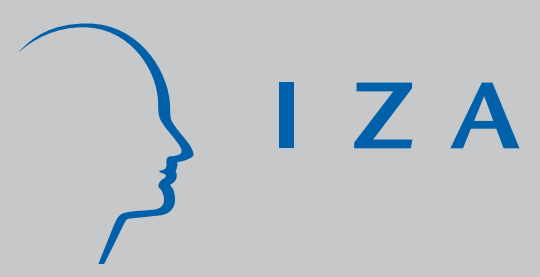

IZA DP No. 1778

Establishment Size and the Dispersion of Wages: Evidence from European Countries

Thierry Lallemand

François Rycx

September 2005 


\title{
Establishment Size and the Dispersion of Wages: Evidence from European Countries
}

\author{
Thierry Lallemand \\ Université Libre de Bruxelles, DULBEA \\ and Centre de Comptabilité, Planning et Contrôle \\ François Rycx \\ Université Libre de Bruxelles, DULBEA \\ and IZA Bonn
}

Discussion Paper No. 1778

September 2005

\author{
IZA \\ P.O. Box 7240 \\ 53072 Bonn \\ Germany \\ Phone: +49-228-3894-0 \\ Fax: +49-228-3894-180 \\ Email: iza@iza.org
}

\begin{abstract}
Any opinions expressed here are those of the author(s) and not those of the institute. Research disseminated by IZA may include views on policy, but the institute itself takes no institutional policy positions.

The Institute for the Study of Labor (IZA) in Bonn is a local and virtual international research center and a place of communication between science, politics and business. IZA is an independent nonprofit company supported by Deutsche Post World Net. The center is associated with the University of Bonn and offers a stimulating research environment through its research networks, research support, and visitors and doctoral programs. IZA engages in (i) original and internationally competitive research in all fields of labor economics, (ii) development of policy concepts, and (iii) dissemination of research results and concepts to the interested public.
\end{abstract}

IZA Discussion Papers often represent preliminary work and are circulated to encourage discussion. Citation of such a paper should account for its provisional character. A revised version may be available directly from the author. 


\section{ABSTRACT}

\section{Establishment Size and the Dispersion of Wages: Evidence from European Countries*}

We investigate how the wage distribution differs among small and large establishments in four European countries. Findings show that within-establishment wage dispersion rises with size because large employers have a more diverse workforce. They also suggest that screening and monitoring costs imply a lower sensitivity of wages to ability in larger establishments. Smaller establishments are found to rely more on incentive-based pay mechanisms, particularly in countries with a low trade union coverage rate. Further results indicate that between-establishment wage dispersion decreases with employer size because smaller establishments are technologically more diversified and hence exhibit greater diversity in average workforce skills.

JEL Classification: J21, J31

Keywords: wage structure, establishment size, decomposition of wages, Europe

Corresponding author:

François Rycx

Université Libre de Bruxelles

CP 140 - Av. F.D. Roosevelt 50

B-1050 Brussels

Belgium

E-mail: frycx@ulb.ac.be

\footnotetext{
* This paper is produced as part of a Targeted Socio-Economic Research (TSER) project on Pay Inequalities and Economic Performance (PIEP) financed by the European Commission (Contract nr. HPSE-CT-1999-00040). The data used in this study come from the 1995 European Structure of Earnings Survey. Due to confidentiality issues, this data set is only available for members of the PIEP research project (http://cep.Ise.ac.uk/piep/).
} 


\section{Introduction}

A strong theoretical and empirical regularity in the economic literature is that on average large employers pay higher wages. ${ }^{1}$ Fewer studies focused on the relationship between employer size and other aspects of the wage structure. However, the theoretical literature has already developed many explanations for a systematic connection between employer size and the dispersion of wages among workers, both within and between establishments. ${ }^{2}$ On the one hand, several hypotheses suggest that within-establishment wage dispersion rises with establishment size because larger establishments (i) employ workers with greater skill heterogeneity (Davis and Haltiwanger, 1995), and (ii) rely more heavily on incentive-based pay schemes (Lazear and Rosen, 1981; McLaughlin, 1988). However, the inverse relationship may prevail if larger employers (i) hire workers with homogeneous skills (Oi, 1983; Kremer, 1993), (ii) use standard pay rate policies to reduce their high monitoring costs (Oi, 1983; Garen, 1985), and (iii) are targets of union drives or mimic unions by compressing wages among workers (Brown et al., 1990; Freeman, 1980, 1982; Voos, 1983). On the other hand, other hypotheses predict that between-establishment wage dispersion is higher at smaller establishments because (i) the latter use a wide range of production technologies (Davis and Haltiwanger, 1995; Lambson, 1991), and (ii) unions are more prevalent among larger establishments which compress wages across occupations (Brown et al., 1990; Freeman, 1980, 1982; Voos, 1983).

As far as we know, the empirical validity of these theories has only been tested by Davis and Haltiwanger (1995). Their study on the US manufacturing sector provides evidence in favour of wage structure differences among employers of different sizes. The authors show that within-establishment wage dispersion increases, in general, with establishment size. They also find that (i) workers' heterogeneity tends to rise with establishment size and that (ii) the contribution of unobserved characteristics to wage dispersion among workers is higher at smaller establishments. On the basis of these results, the authors attribute the positive relationship between establishment size and within-establishment wage dispersion to higher heterogeneity in workforce skills in large establishments. In other words, their results do not support the hypothesis that within-establishment wage dispersion increases with size due to stronger incentive-based pay schemes in larger establishments. Finally, they show that between-establishment wage dispersion decreases with establishment size. The authors 
attribute this result to the hypothesis that smaller employers are technologically more diverse than large employers (i.e. to Lambson's theory of life-cycle dynamics of firms (1991)).

The present paper contributes to this literature by examining the relationship between establishment size and wage dispersion in four European countries, i.e. Belgium, Ireland, Italy and Spain. To do so, we use a unique harmonised matched employer-employee data set, i.e. the 1995 European Structure of Earnings Survey (ESES). Although matched employeremployee data sets are now available for a number of individual countries, to the best of our knowledge, the ESES provides the only multi-country data set with matched employeremployee data. This survey contains detailed information, reported by the management of the establishments, both on individual workers (e.g. gross hourly wages, bonuses, age, education, tenure, sex, occupation) and employers' characteristics (e.g. sector of activity, region, level of wage bargaining, size of the establishment).

Our methodology rests upon a two-step estimation procedure. Firstly, we rely on the full distribution accounting methodology developed in 1993 by Juhn, Murphy and Pierce (hereafter, JMP). Secondly, we break down the variance of wages into between- and withinestablishment components according to Davis and Haltiwanger $(1991,1995)$ and Hibbs and Locking (2000). The JMP methodology characterizes the effects of changing, respectively: (i) the returns to observed characteristics (price effect), (ii) the distribution of observed characteristics (quantities effect) and (iii) the residuals (residual effect) on wage dispersion among workers in small and large establishments. For our study, we use a special version of the JMP methodology as it was suggested by Lemieux (2002, pp. 666). The advantage of such a procedure is that it allows to isolate the contribution of returns to unmeasured workers' characteristics (e.g. ambition, initiative, effort). Therefore, the residual effect may be economically interpreted as an indicator of the diversity in compensation schemes across employers of different sizes. Finally, we take advantage of our cross-country perspective to examine whether the effects of changing the pricing function of observed and unobserved characteristics (i.e. price and residual effects, respectively) depend upon collective bargaining characteristics.

The remainder of this paper is organised as follows. Section II reviews the factors that may generate wage structure differences among employers of different sizes. Section III describes the data. Section IV analyses the differences in the wage distribution among size classes. In section $\mathrm{V}$, we separate the variance of wages into between- and withinestablishment components. The last section concludes. 


\section{Determinants of wage dispersion among employers of different sizes}

\subsection{Theory}

There is no consensus in the theoretical literature about the determinants of wage dispersion among employers of different sizes. However, three broad categories of factors are generally put forward (Davis and Haltiwanger, 1995): the degree of technological diversity, noncompetitive and institutional factors, and compensation schemes. These factors interact with employer size to either increase or decrease within- and between-establishment components of wage dispersion.

Production technologies used by establishments call for different kinds of workforce skills. Consequently, if employers of different sizes adopt various technologies, there could be differences in wage dispersion by establishment size. One can assume that if large employers are more diversified horizontally and vertically, the latter engage in a greater variety of tasks and need workers with more heterogeneous skills (Davis and Haltiwanger, 1995). Therefore, within-establishment wage dispersion should rise with employer size. However, Oi (1983) and Kremer (1993) expect the inverse relationship. In Oi's view, larger employers use standardised production technologies which call for a homogeneous workforce. Kremer (1993) argues that large employers adopt technologies with high skill complementarities which generate a lower dispersion of skills among workers. Davis and Haltiwanger (1995) rely on Lambson's theory of life-cycle dynamics of plants (1991) to suggest that betweenestablishment wage dispersion decreases with employer size. They assume that smaller employers are young and will experience different technologies of production over time. Only those with a successful technology survive and become larger. In other words, the higher variety of production technologies between smaller establishments should lead to a greater diversity in average workforce skills. Therefore, between-establishment wage dispersion should be higher among smaller employers.

Wage structure differences can also arise from rent-sharing and from the diversity in workers' ability to extract rents across establishments of different sizes. Indeed, Davis and Haltiwanger (1995) suggest that intra-establishment wage dispersion depends on heterogeneity in workers' bargaining power. Assuming that high skilled workers have a stronger ability to extract rents and that large establishments employ on average more heterogeneous workers, differences in the bargaining power of workers are possibly stronger 
within large establishments. Hence, the dispersion of wages within establishments may increase with employer size.

Trade unions may also influence the structure of wages within and between establishments of different sizes. Several studies investigating differences in wage inequalities between unionised and non-unionised establishments have shown that unions (i) make compensation schemes uniform across establishments and (ii) tend to compress wages (Freeman, 1980, 1982; Gosling and Machin, 1994). In other words, within- and betweenestablishment wage dispersions are found to be lower within unionised establishments. It also appears that union power or threat is in general stronger within large companies (Brown et al., 1990; Voos, 1983). Therefore, we may expect both between- and within-establishment dispersion of wages to fall with employer size. In continental Europe, the bargaining regime is quite different from the US pattern. Indeed, wage bargaining occurs at different levels: national, sectoral, regional and/or local. Several studies have shown that the level of collective wage bargaining has an impact on the dispersion of wages within and between establishments (Dell'Aringa and Lucifora, 1994; Dell'Aringa et al., 2004; Dominguez and Gutierrez, 2004). However, there is no consensus about the sign of this effect. Therefore, it is not clear whether large establishments, which are expected to renegotiate wages more frequently at the local level, should exhibit higher or lower levels of wage dispersion.

A last factor influencing the internal structure of wages is the type of compensation scheme. Tournament theories suggest that employers should implement some wage dispersion in order to foster the average worker's effort (Lazear and Rosen, 1981). McLaughlin (1988) adds that the higher the number of contestants for a prize (e.g. bonus or promotion) the larger must be the wage differential to enhance worker's productivity. Accordingly, withinestablishment wage dispersion is expected to rise with establishment size. However, considering an organisation in which some workers are non-cooperative ('hawks') while others are less aggressive ('doves'), Lazear $(1989$, 1995) argues that if workers can affect each other's output, standard pay rate policies could be more efficient. Also noteworthy is that efficiency wage models predict that wage differentials based on size differences can emerge from the higher monitoring costs borne by large employers. Indeed, Garen (1985) supposes that monitoring and screening costs are higher for large employers, and reduce their ability to differentiate wages according to workers' unobserved characteristics (e.g. initiative, ambition, effort). In sum, assuming that monitoring costs are higher within large establishments and/or that workers are less cooperative in the latter, intra-establishment wage dispersion should fall with employer size. 


\subsection{Previous results}

As far as we know, Davis and Haltiwanger (1995) provide the only empirical analysis of the determinants of wage dispersion among employers of different sizes. Their study on the US manufacturing sector in 1982 shows the existence of wage structure differences among employers of different sizes. On the one hand, they use the full distribution accounting methodology of Juhn, Murphy and Pierce (1993) in order to investigate how the wage distribution varies with establishment size. On the other hand, they examine how wage dispersion breaks down into within- and between-establishment components according to size. The authors show that within-establishment wage dispersion increases, in general, with establishment size. They also find that (i) workers' heterogeneity tends to rise with establishment size and that (ii) the contribution of unobserved characteristics to wage dispersion among workers is larger at smaller establishments. On the basis of these results, the authors attribute the positive relationship between establishment size and within-establishment wage dispersion to greater heterogeneity in workers' skills within large establishments. In other words, their results do not support the hypothesis that within-establishment wage dispersion increases with size due to stronger incentive-based pay schemes in larger establishments. Finally, they find that between-establishment wage dispersion decreases with establishment size. The authors attribute this result to the hypothesis that smaller employers are technologically more diverse than large employers.

\section{Data}

The present study is based on the 1995 European Structure of Earnings Survey, gathered by Eurostat. This harmonised survey, covering four European countries (i.e. Belgium, Ireland, Italy, and Spain), contains a wealth of information, provided by the management of the establishments, both on individual workers (e.g. gross hourly wages, bonuses, age, education, tenure, sex, occupation) and employers' characteristics (e.g. sector of activity, size of the establishment, level of wage bargaining). Interestingly, establishment size is measured by the exact number of employees. Hence, it avoids potential measurement errors present in studies where categorized employer-size data are converted into a continuous measure of establishment size (Albaek et al., 1998). The ESES is representative of all establishments employing at least ten workers and whose economic activities fall within sections $\mathrm{C}$ to $\mathrm{K}$ of 
the Nace Rev. 1 nomenclature ${ }^{3}$, except for Ireland where sectors F, I and K are not covered. The number of observations in our sample ranges between 36,491 in Ireland and 166,567 in Spain.

The means and standard deviations of key variables broken down by establishment size are given in Appendix I. We have split our sample such that the number of workers is (i) equal or above 10 and below 150 in small establishments and (ii) at least equal to 150 in large establishments. ${ }^{4}$ We note a significant difference between the mean characteristics of workers employed in small and large establishments. The point is that on average individuals employed in large establishments earn higher wages, are more educated, have less potential experience, and more years of seniority. Moreover large establishments tend to be better represented in financial intermediation, to employ more white-collar workers, and to pay bonuses for overtime, shift work, night work and/or weekend work to a larger fraction of their workforce.

\section{Wage dispersion differences among small and large establishments}

\subsection{Methodology}

In order to analyse the structure of wages among establishments of different sizes, we rely on a particular version of the decomposition procedure of Juhn, Murphy and Pierce (1993). The JMP methodology decomposes change in the wage distribution over time in three components: changes in the returns to observed characteristics (price effect), changes in the distribution of observables (quantities effect) and residual changes (residual effect). For our study, we use a special version of the JMP methodology as it was suggested by Lemieux (2002). The advantage of such a procedure is that it allows to isolate the contribution of returns to unmeasured workers' characteristics (e.g. ambition, initiative, effort). Therefore, the residual effect may be economically interpreted as an indicator of the diversity in compensation schemes across employers of different sizes. This particular version of the JMP

3. It thus covers the following sectors: i) mining and quarrying (C), ii) manufacturing (D), iii) electricity, gas and water supply (E), iv) construction (F), v) wholesale and retail trade, repair of motor vehicles, motorcycles and personal and household goods $(\mathrm{G})$, vi) hotels and restaurants $(\mathrm{H})$, vii) transport, storage and communication (I), viii) financial intermediation (J), and ix) real estate, renting and business activities (K).

4. However, as a sensitivity test, we further change the composition of the two size classes (i.e. with a cut point at 100 and at 200 workers instead of 150). 
methodology also modifies the quantities effect, which results from a mix of the effects of changes in the covariates plus the change unexplained by the price and residual effects. In other words, the quantities effect measures the contribution of changing the distribution of observed and unobserved characteristics to wage dispersion.

We run this special version of the JMP decomposition for several wage dispersion measures. More precisely, we examine the price, residual and quantities effects for the variance of wages and for the gap between two percentiles of the log wage distribution (i.e. the $90-10,90-50$ and 50-10 log wage differentials). We apply this methodology to the following wage regression:

$$
\mathrm{W}_{\mathrm{ij}}=\mathrm{X}_{\mathrm{ij}} \beta_{\mathrm{j}}+\varepsilon_{\mathrm{ij}},
$$

where $\mathrm{W}_{\mathrm{ij}}$ is the log of gross hourly wages (including bonuses) $)^{5}$ of individual $i$ in size class $j$. $\mathrm{X}_{\mathrm{ij}}$ is a vector of observed worker and establishment characteristics. It includes: 5 dummies for education, prior potential experience (in level, squared and cubed), tenure (in level and squared), occupation (19 dummies), and a dummy for the sex of the individual. It also contains dummies for: industry affiliation in Nace 2 digit $^{6}$, region where the establishment is located $^{7}$, economic and financial control ${ }^{8}$, level of collective wage bargaining, ${ }^{9}$, working conditions $^{10}$ and monitoring ${ }^{11}$. Other theories explaining the size-wage premium emphasize that large firms match more skilled workers together (Kremer and Maskin, 1996; Troske,

5. The gross hourly wage includes overtime paid, premiums for shift work, night work and/or weekend work and bonuses (i.e. irregular payments which do not occur during each pay period, such as pay for holiday, $13^{\text {th }}$ month, profit sharing, etc.).

6. Belgium and Italy (41 dummies), Ireland (33 dummies). In Spain we control for the sectors in Nace 1 digit ( 8 dummies).

7. Belgium (2 dummies), Ireland (none), Italy (10 dummies) and Spain (6 dummies).

8. Belgium (3 dummies), Ireland (2 dummies), Italy (none) and Spain (3 dummies).

9. For Belgium, we add 2 dummies, i.e. for establishments covered by: i) an enterprise collective agreement (CA), and ii) other pay-setting arrangements. For Ireland, we add 1 dummy, i.e. for establishments covered by an enterprise CA. For Italy, we add 3 dummies, i.e. for establishments covered by: i) an enterprise CA, ii) an establishment CA, and iii) other pay-setting arrangements. For Spain, we add 4 dummies, i.e. for establishments covered by: i) an above-enterprise CA (provincial/regional level or within sectors at the provincial/regional level), ii) an enterprise $\mathrm{CA}$, iii) an establishment $\mathrm{CA}$, and iv) other pay-setting arrangements. In all countries, the left out reference group is composed of establishments solely covered by national and/or sectoral CAs.

10. Type of contract ( 2 dummies), ln of paid hours, a dummy for paid overtime hours, and a dummy for premium payments associated with shift work, night-time and/or weekend work.

11. Dummy variable showing whether the individual supervises the work of his co-workers. 
1999) and create internal labour markets in order to increase the stability of their workforce (Idson, 1996). To account for these elements, we add as control variables: the percentage of highly educated individuals per establishment (i.e. workers with long- and short-type higher education), the workers' mean years of potential experience per establishment, and the workers' mean years of tenure per establishment. $\varepsilon_{\mathrm{ij}}$ is the part of the wage unaccounted for by observables. In this paper, we specify a special structure for the residuals. As suggested by Lemieux (2002, pp. 666), we suppose that $\varepsilon_{\mathrm{ij}}=\mathrm{p}_{\mathrm{j}}\left(\eta_{\mathrm{ij}}\right)+\mathrm{u}_{\mathrm{ij}}$ where $\mathrm{p}_{\mathrm{j}}($.$) is a monotonic and$ continuous function and where we assume for simplicity that $\mathrm{u}_{\mathrm{ij}}=0$. We also let $\eta_{\mathrm{ij}}$ follow a uniform distribution over the $[0,1]$ interval. This is quite convenient since $\eta_{\mathrm{ij}}=\mathrm{F}_{\mathrm{j}}\left(\varepsilon_{\mathrm{ij}}\right)$ where $F_{j}($.$) is the cumulative distribution function of \varepsilon_{i j}$. Therefore, $\varepsilon_{i j}=p_{j}\left(\eta_{i j}\right)=F_{j}^{-1}\left(\eta_{i j}\right)$. Lemieux (2002) notes that $\eta_{\mathrm{ij}}$ can be interpreted as the rank (normalized from 0 to 1 ) of observation $i$ in the distribution of the residuals while the non-linear skill price function $p_{j}($.$) is the inverse$ of the cumulative distribution function of $\varepsilon_{\mathrm{ij}}$.

Suppose that we run Lemieux's version of the JMP decomposition (2002) for large establishments. Firstly, we estimate by OLS the log wages of workers in size class $L$ :

$$
\mathrm{W}_{\mathrm{iL}}=\mathrm{X}_{\mathrm{iL}} \beta_{\mathrm{L}}+\mathrm{F}_{\mathrm{L}}^{-1}\left(\eta_{\mathrm{iL}}\right),
$$

and examine the actual dispersion of wages among workers in large establishments.

Secondly, we build a counterfactual distribution of wages. In other words, we replace $\beta_{\mathrm{L}}$ by $\beta_{\mathrm{s}}$ (i.e. the price or return to observed characteristics in small establishments):

$$
\mathrm{W}_{\mathrm{iL}}^{\mathrm{A}}=\mathrm{X}_{\mathrm{iL}} \beta_{\mathrm{S}}+\mathrm{F}_{\mathrm{L}}^{-1}\left(\eta_{\mathrm{iL}}\right) \text {. }
$$

The price effect emerges from the difference in wage dispersion between (2) and (3). To put it differently, we assess the contribution of changing the returns to observed characteristics in the large size class on the level of wage dispersion among workers in large establishments. Thirdly, we replace the residuals in size class $L$ by the residuals that would prevail if the unobserved pricing function were $\mathrm{p}_{\mathrm{S}}($.$) instead of \mathrm{p}_{\mathrm{L}}(.){ }^{12}$ This amounts to calculating a new wage for each individual $i$ in size class $L$ by keeping the $\beta_{\mathrm{S}}$, which gives:

12. Empirically, it is difficult to exactly match large and small size classes' residuals at a specific rank (since the two size categories do not offer the same number of observations). A simple solution, suggested by Lemieux (2002, pp. 669), is to discretize the cumulative distribution function of the residuals into $\mathrm{k}$ number of intervals containing a (quite) similar number of observations. In this paper, we use $\mathrm{k}=1,000$ and replace the actual value of residuals by the average residuals in each interval. 


$$
\mathrm{W}_{\mathrm{iL}}^{\mathrm{B}}=\mathrm{X}_{\mathrm{iL}} \beta_{\mathrm{S}}+\mathrm{F}_{\mathrm{S}}^{-1}\left(\eta_{\mathrm{iL}}\right) .
$$

The residual effect is equal to the difference in wage dispersion between (3) and (4). To put it differently, we determine how wage dispersion among workers in large establishments is influenced by changing the pricing function of unobserved characteristics. Finally, we estimate the wages of workers in size class $S$ :

$$
\mathrm{W}_{\mathrm{iS}}=\mathrm{X}_{\mathrm{iS}} \beta_{\mathrm{S}}+\mathrm{F}_{\mathrm{S}}^{-1}\left(\eta_{\mathrm{iS}}\right) \text {. }
$$

An estimate of the quantities effect is obtained through the wage dispersion difference between (4) and (5). It results from determining what would be the new wage dispersion in large establishments if we change the distribution of $\mathrm{X}_{\mathrm{iL}}$ (i.e. if we attribute the distribution of observed characteristics in small establishments to the large size class) and the distribution of $\varepsilon_{\text {iL }}$ (i.e. if we assign the distribution of unmeasured skills in small establishments to the large size class). Equations (2) and (5) are estimated by OLS with White (1980) heteroscedasticityconsistent standard errors. Moreover, to rule out the bias in the estimated standard errors stemming from the use of aggregated establishment variables in an individual wage equation, we apply the correction for common variance components within groups as suggested by Greenwald (1983) and Moulton (1990). ${ }^{13}$

As mentioned by Lemieux (2002), the results of the decomposition may be sensitive to (i) the order in which each factor is analysed because of interactions between price and residual effects and also to (ii) the size class reference of the decomposition. For instance, instead of using $\mathrm{W}_{\mathrm{iL}}^{\mathrm{A}}$ we can build other wages, when we solely change the pricing function of unobserved characteristics:

$$
\mathrm{W}_{\mathrm{iL}}^{\mathrm{C}}=\mathrm{X}_{\mathrm{iL}} \beta_{\mathrm{L}}+\mathrm{F}_{\mathrm{S}}^{-1}\left(\eta_{\mathrm{iL}}\right) \text {. }
$$

The residual effect is then obtained through the difference between wage dispersion in (2) and (6). The difference with our first specification is that the effect of changing the pricing function of unobserved characteristics is based on wages for which we keep $\beta_{L}$. Besides, the price effect results from the difference between wage dispersion in (6) and (4). In other words, this effect is derived from wages for which the pricing function of unobserved characteristics has changed. That is why it is meaningful to test the robustness of the results by changing the specification (i.e. using $\mathrm{W}_{\mathrm{ij}}^{\mathrm{C}}$ instead of $\mathrm{W}_{\mathrm{ij}}^{\mathrm{A}}$ ) and the order (i.e. taking small establishments as size class reference for the decomposition) of the decomposition.

13. See Appendix II for the detailed results of wage regressions in small and large establishments. 


\subsection{General analysis}

In this section, we suppose that the number of workers in small establishments is equal to or above 10 and below 150, while large establishments employ a minimum of 150 workers. ${ }^{14} \mathrm{~A}$ first result arising from rows 1 and 4 of Table 1 is that wage dispersion in small and large establishments, measured either by the variance of log wages or by the 90-10 log wage differential, is higher in Ireland and Spain than in Italy and Belgium. Moreover, large establishments exhibit more wage dispersion (see row 5 of Table 1). However, the pattern is quite different at both ends of the entire wage distribution. Larger establishments appear to compress wages more heavily in the upper half of the wage distribution and to strongly differentiate wages in the lower half of the wage distribution (except in Ireland, see row 5 of Table 2). Finally, it is noteworthy that wage inequality differences between small and large establishments are stronger in the lower half of the wage distribution (except in Ireland).

In what follows, we try to identify the determinants of such wage dispersion differences between small and large establishments by running Lemieux's version of the JMP decomposition (2002) and taking large establishments as size class reference.

\section{[Take in Table 1]}

[Take in Table 2]

Row 6 of Table 1 indicates a negative price effect on the variance of log wages and on the 90-10 log wage differential among workers in large establishments. To put it differently, replacing the returns to observed characteristics in large establishments by those with small employers increases overall wage dispersion in large establishments. These results suggest that smaller employers are more able to differentiate wages on the basis of observed characteristics. Moreover, we find a residual effect which is also negative (see row 7 of Table 1). In other words, assigning the unobserved skills pricing function of small establishments to workers with larger employers increases overall wage dispersion among workers in large establishments. Unobserved factors tend to contribute substantially more to wage dispersion in smaller establishments. This finding does not seem to support tournament theory which

14. Further, we test the sensitivity of the results by changing the composition of the two size classes (i.e. with a cut point at 100 and 200 workers, respectively). 
suggests that large employers have to implement more pay spread in order to stimulate workers' efforts (McLaughlin, 1988). Indeed, it is more in line with the hypothesis that screening and monitoring costs are lower in small establishments (Garen, 1985). Therefore, the latter may rely more intensively on incentive-based pay schemes to enhance workers' productivity. Comparable results were found by Davis and Haltiwanger (1995) for production and non-production workers within the US manufacturing sector. Also noteworthy is that recent studies have shown that unmeasured skills are better rewarded in smaller firms because of lower monitoring costs (Ferrer and Lluis, 2004; Silva, 2004).

Rows 6 and 7 of Table 1 indicate that the price and residual effects are stronger in Ireland and Spain than in Belgium and Italy. In seeking to explain the diversity of these effects, we examine their correlation with several collective bargaining characteristics, i.e. the degree of centralisation, the degree of coordination, the trade union coverage rate, and trade union density. ${ }^{15}$ Results, reported in Table A3 of Appendix III, point out the existence of a significant and negative relationship between the absolute value of the price and residual effects and two collective bargaining characteristics, i.e. the degree of coordination, and the trade union coverage rate. To put it differently, results suggest that smaller employers rely more heavily on incentive-based pay schemes that tie wages to observed and unobserved characteristics (e.g. pay-for-performance systems) in countries with a lower coordination degree and trade union coverage rate. Yet, caution is required since results are based on four data points only.

Row 8 of Table 1 indicates a positive quantities effect on the variance of log wages and on the 90-10 log wage differential in larger establishments. This result suggests that assigning the distribution of observed and unobserved characteristics that would prevail in small establishments to workers in large establishments reduces wage dispersion among workers within the latter size class. Finally, Table 2 presents the JMP results in the upper and lower

15. The degree of centralisation refers strictly to the principal level at which bargaining occurs (establishment, firm, industry or national). In contrast, the degree of coordination among the social partners refers to the ability of trade unions and employers' organisations to coordinate their decisions both horizontally (within a given bargaining level) and vertically (between different bargaining levels). Coordination might be 'overt' or 'covert'. Overt or direct coordination refers to the explicit pursuit of economy-wide coordination goals by the principal bargaining agents (i.e. peak associations of business and labour, possibly joined by the government agencies in tripartite arrangements). In contrast, covert or indirect coordination is achieved through the internal governance of the associations and/or through the pace-setting role of bargaining in key sectors (for a more detailed discussion see e.g. $\operatorname{OECD}(1997,2004))$. 
half of the log wage distribution. In general, the price and residual effects are negative and the quantities effect is positive. In other words, results are quite similar at both ends of the wage distribution.

\subsection{Sensitivity analysis}

In order to test the robustness of the results, we adopt several other specifications. Firstly, as suggested by Lemieux (2002), we change the order of analysing the residual and price effects. We compute the residual effect through wages based on the returns to observed characteristics of the large size class and afterwards we analyse the price effect which is based on the pricing function of unmeasured skills in small establishments. Secondly, we use smaller establishments as the reference size class for the wage decomposition. Finally, we adopt two other criteria to categorize an establishment as small or large. For the first specification, we let the small size class be composed of establishments with at least 10 workers and a maximum of 99 individuals. For the second specification, the maximum number of workers for small establishments is set at 199. In general, whatever the specification, results are quite similar to those obtained in the previous section. ${ }^{16}$

\section{Between- and within-establishment components of wage dispersion}

In section 2, we showed that theories on wage dispersion among workers in different size classes are quite conflicting. Results obtained with the JMP decomposition indicate that several hypotheses can explain wage dispersion differences among small and large establishments. In order to get some additional insight on the determinants of wage dispersion, we decompose the variance of log wages into between- and within-establishment components.

\subsection{Methodology}

We rely on the methodologies of Davis and Haltiwanger $(1991,1995)$ and Hibbs and Locking (2000) to explain the total variance of log wages by: a within-establishment component, a

16. Results are available upon request. 
between-establishment component and a mean wage gap between small and large establishments.

$$
\begin{aligned}
& \mathrm{V}=\alpha\left(\mathrm{V}^{\mathrm{S}}\right)+(1-\alpha) \mathrm{V}^{\mathrm{L}}+\alpha(1-\alpha)\left(\overline{\mathrm{W}}^{\mathrm{S}}-\overline{\mathrm{W}}^{\mathrm{L}}\right)^{2} \\
& \mathrm{~V}=\alpha\left(\mathrm{V}_{\mathrm{BE}}^{\mathrm{S}}+\mathrm{V}_{\mathrm{WE}}^{\mathrm{S}}\right)+(1-\alpha)\left(\mathrm{V}_{\mathrm{BE}}^{\mathrm{L}}+\mathrm{V}_{\mathrm{WE}}^{\mathrm{L}}\right)+\alpha(1-\alpha)\left(\overline{\mathrm{W}}^{\mathrm{S}}-\overline{\mathrm{W}}^{\mathrm{L}}\right)^{2}
\end{aligned}
$$

Superscript S denotes small establishments and L large establishments. $\alpha$ is the employment share of small establishments. $\mathrm{V}^{\mathrm{S}}$ and $\overline{\mathrm{W}}^{\mathrm{S}}$ refer respectively to the variance and the mean of $\log$ wages among small establishments. $\mathrm{V}_{\mathrm{BE}}^{\mathrm{S}}$ denotes between-establishment wage dispersion among workers in small establishments (i.e. the variance of mean wages per establishment). $\mathrm{V}_{\mathrm{WE}}$ is the within-establishment component of wage dispersion and is expressed as a residual in a standard variance decomposition:

$$
\hat{\mathrm{V}}_{\mathrm{WE}}^{\mathrm{S}}=\mathrm{V}^{\mathrm{S}}-\mathrm{V}_{\mathrm{BE}}^{\mathrm{S}}
$$

\subsection{Results}

Table 3 reports the results of the decomposition in equation (7). In general, betweenestablishment wage dispersion accounts for a greater share of the total variance in log wages than the within-establishment component (i.e. an average of around 50\% vs. 40\%).

\section{[Take in Table 3]}

Table 3 indicates that within-establishment wage dispersion increases with employer size and that the dispersion in mean wages between establishments is notably higher in smaller establishments. In order to understand these results, it is useful to recall two previous findings: (i) workers' heterogeneity tends to rise with employer size (i.e. positive quantities effect) and (ii) unobserved characteristics contribute far more to overall wage dispersion in smaller establishments (i.e. negative residual effect). Therefore, we may argue that large establishments exhibit higher within-plant wage dispersion because they are more diversified horizontally and vertically, engage in a higher variety of tasks and hence select a relatively more heterogeneous workforce. Since unobserved characteristics contribute far more to wage dispersion in smaller establishments, tournament models cannot explain the positive relationship between employer size and the dispersion of wages within establishments. Moreover, our results suggest that smaller establishments are more able to differentiate wages 
on the basis of unobserved workers' characteristics because of lower screening and monitoring costs (Garen, 1985). On the other hand, we may also use the results regarding workers' heterogeneity to explain why the dispersion of mean wages between plants is higher at smaller establishments. The idea is that the latter are technologically more diverse than large employers. Indeed, Lambson's theory of life-cycle dynamics of plants (1991) assumes that smaller employers are young and experience different technologies of production over time. Only those with a successful technology survive and become larger. To put it differently, a higher variety of production technologies between smaller establishments leads to greater diversity in average workforce skills. As suggested by Davis and Haltiwanger (1995), who obtained quite similar results for workers in the US manufacturing sector, it is difficult to discriminate between the two interpretations based on workers' heterogeneity. However, the decomposition of the variance in wages into within- and between-establishment components strongly supports the heterogeneity interpretation that suggests an increase in within-establishment wage dispersion with employer size.

\section{Conclusion}

This paper examines the relationship between establishment size and wage dispersion in four European countries. To do so, we rely on a unique harmonised matched employer-employee data set, i.e. the 1995 European Structure of Earnings Survey (ESES). This survey contains detailed information, reported by the management of the establishments, both on individual workers (e.g. gross hourly wages, bonuses, age, education, tenure, sex, occupation) and employers' characteristics (e.g. sector of activity, region, level of wage bargaining, size of the establishment). Our methodology rests upon a two-step estimation procedure. Firstly, we use Lemieux's version (2002) of the full distribution accounting methodology developed initially by Juhn, Murphy and Pierce (1993). Secondly, we separate the variance of wages into between- and within-establishment components.

Empirical findings suggest that within-establishment wage dispersion rises with size because large employers have a more heterogeneous workforce. However, they support the hypothesis that screening and monitoring costs imply less sensitivity of wages to ability in larger establishments (Garen, 1985). They also suggest that smaller establishments rely more heavily on incentive-based pay mechanisms, particularly in countries with a low degree of coordination and trade union coverage rate. Final results indicate that between-establishment wage dispersion decreases with employer size because smaller establishments are 
technologically more diversified and hence exhibit far more diversity in average workforce skills. These findings seem to support the Lambson's theory of life-cycle dynamics of plants (1991).

To the best of our knowledge, the only comparable study on the relationship between establishment size and wage dispersion has been realised by Davis and Haltiwanger (1995) for the US manufacturing sector. Interestingly, results reported in this paper are quite similar to those reported by the latter.

\section{References}

Albaek, K., Arai, M., Asplund, R., Barth, E. and Madsen, E. (1998). 'Measuring wage effects of plant size', Labour Economics, Vol. 5, pp. 425-448.

Brown, C., Hamilton, J. and Medoff, J. (1990). Employers Large and Small, Cambridge (MA): Harvard University Press.

Davis, S. J. and Haltiwanger, J. (1991). 'Wage dispersion between and within U.S. manufacturing plants: 1963-1986', Brooking Papers on Economic Activity: Microeconomics, pp. 115-200.

Davis, S. J. and Haltiwanger, J. (1995). Employer Size and the Wage Structure in the U.S. Manufacturing, NBER Working Paper No. 5393, National Bureau of Economic Research, Cambridge (MA).

Dell'Aringa, C. and Lucifora, C. (1994). 'Wage dispersion and unionism: do unions protect low pay?', International Journal of Manpower, Vol. 15, pp. 150-170.

Dell'Aringa, C., Lucifora, C., Orlando, N. and Cottini, E. (2004). Bargaining Structure and Intra-establishment Wage Inequality in four European Countries: Evidence from Matched Employer-employee Data, PiEP Working Paper, London School of Economics, London.

Dominguez, J. F. and Gutierrez, C. R. (2004). 'Collective bargaining and within-firm wage dispersion in Spain', British Journal of Industrial Relations, Vol. 42, pp. 481-506.

European Industrial Relations Observatory (2002). Industrial Relations in the EU Member States and Candidate Countries, Working Paper, European Foundation for the Improvement of Living and Working Conditions.

Ferrer, A. and Lluis, S. (2004). Should Workers Care about Firm Size?, HRRI Working Paper No. 0204, University of Minnesota, Industrial Relations Center. 
Freeman, R. (1980). 'Unionism and the dispersion of wages', Industrial and Labor Relations Review, Vol. 34, pp.3-23.

Freeman, R. (1982). 'Union wage practices and wage dispersion within establishments', Industrial and Labor Relations Review, Vol. 36, pp. 3-21.

Garen, J. (1985). 'Worker heterogeneity, job screening, and firm size', Journal of Political Economy, Vol. 93, pp. 715-739.

Gosling, A. and Machin, S. (1994). 'Trade unions and the dispersion of earnings in British establishments, 1980-90', Oxford Bulletin of Economics and Statistics, Vol. 57, pp. 16784.

Greenwald, B. (1983). 'A general analysis of bias in the estimated standard errors of least square coefficients', Journal of Econometrics, Vol. 22, pp. 323-338.

Hibbs, D. Jr and Locking, H. (2000). 'Wage dispersion and productive efficiency: evidence for Sweden', Journal of Labor Economics, Vol. 18, pp. 755-782.

Idson, T. L. (1996). 'Employer size and labor turnover', in Polatchek, S. W. (ed.), Research in Labor Economics, Vol. 15, Greenwich, CT: JAI Press: pp. 273-304.

Juhn, C., Murphy, K. and Pierce, B. (1993). 'Wage inequality and the rise in returns to skill', Journal of Political Economy, Vol. 101, pp. 410-442.

Kremer, M. (1993). 'The o-ring theory of economic development', Quarterly Journal of Economics, Vol. 108, pp. 551-575.

Kremer, M. and Maskin, E. (1996). Segregation by Skill and the Rise in Inequality, NBER Working Paper No. 5718, National Bureau of Economic Research, Cambridge (MA).

Lambson, V. E. (1991). 'Industry evolution with sunk costs and uncertain market conditions', International Journal of Industrial Organization, Vol. 9, pp. 171-196.

Lazear, E. P. (1989). 'Pay equality and industrial politics', Journal of Political Economy, Vol. 97, pp. 561-580.

Lazear, E. P. (1995). Personnel Economics, Cambridge (MA): MIT Press.

Lazear, E. P. and Rosen, S. (1981). 'Rank-order tournaments as optimum labor contracts', Journal of Political Economy, Vol. 89, pp. 841-864.

Lemieux, T. (2002). 'Decomposing wage distributions: a unified approach', Canadian Journal of Economics, Vol. 35, pp. 646-688.

McLaughlin, K. (1988). 'Aspects of tournaments models: a survey', Journal of Labor Economics, Vol. 15, pp. 403-430. 
Moulton, B. R. (1990). 'An illustration of a pitfall in estimating the effects of aggregate variables on micro units', Review of Economics and Statistics, Vol. 72, pp. 334-338.

Nickell, S. and Layard, R. (1999). 'Labor market institutions and economic performance', in Ashenfelter, O. and Card, D. (eds.), Handbook of Labor Economics, Vol. 3, Amsterdam: North Holland, pp. 3029-3084.

OECD (1997). Employment Outlook, OECD, Paris.

OECD (2004). Employment Outlook, OECD, Paris.

Oi, W. Y. (1983). 'The fixed costs of specialized labor', in Triplett, J. (ed.), The Measurement of Labor Cost, Chicago: University of Chicago Press.

Oi, W. Y. and. Idson, T. L (1999). 'Firm size and wages', in Ashenfelter, O. and Card, D. (eds.), Handbook of Labor Economics, Vol. 3, Amsterdam: North Holland, pp. 21662214

Silva, J. (2004). Estimating the Employer Size-Wage Premium in a Panel Data Model with Comparative Advantage and Non-random Selection, NIPE Working Paper, Universidade do Minho.

Traxler, F., Blaschke, S. and Kittel, B. (2001). National Labour Relations in Internationalized Markets. A Comparative Study of Institutions, Change and Performance. Oxford: Oxford University Press.

Troske, K. R. (1999). 'Evidence on the employer-size wage premium from workerestablishment matched data', Review of Economics and Statistics, Vol. 81, pp. 1-12.

Voos, P. (1983). 'Union organizing: costs and benefits', Industrial and Labor Relations Review, Vol. 36.

White, H. (1980). 'A heteroscedasticity-consistent covariance matrix estimator and a direct test for heteroscedasticity', Econometrica, Vol. 48, pp. 817-830. 
Table 1

JMP decomposition of the variance and 90-10 log wage differential among small and large establishments

\begin{tabular}{|c|c|c|c|c|c|c|c|c|}
\hline & \multicolumn{2}{|c|}{ Belgium } & \multicolumn{2}{|c|}{ Ireland } & \multicolumn{2}{|c|}{ Italy } & \multicolumn{2}{|c|}{ Spain } \\
\hline & Variance & 90-10 gap & Variance & 90-10 gap & Variance & 90-10 gap & Variance & 90-10 gap \\
\hline 1. Large & 0.155 & 0.982 & 0.333 & 1.403 & 0.167 & 0.960 & 0.272 & 1.327 \\
\hline 2. Large with $\beta_{\mathrm{S}}$ & 0.165 & 0.996 & 0.370 & 1.532 & 0.167 & 0.978 & 0.284 & 1.356 \\
\hline 3. Large with $\beta_{\mathrm{S}}$ and $\mathrm{X}_{\mathrm{S}}$ & 0.174 & 1.001 & 0.390 & 1.557 & 0.176 & 0.990 & 0.295 & 1.378 \\
\hline 4. Small & 0.165 & 0.917 & 0.324 & 1.391 & 0.154 & 0.912 & 0.271 & 1.229 \\
\hline 5. Large-Small (1-4) & -0.010 & 0.064 & 0.010 & 0.013 & 0.013 & 0.048 & 0.001 & 0.098 \\
\hline \multicolumn{9}{|l|}{ Effect of: } \\
\hline 6. Price $(1-2)$ & -0.010 & -0.014 & -0.037 & -0.129 & 0.000 & -0.018 & -0.012 & -0.029 \\
\hline 7. Residual (2-3) & -0.009 & -0.005 & -0.019 & -0.025 & -0.009 & -0.013 & -0.011 & -0.023 \\
\hline 8. Quantities (3-4) & 0.009 & 0.083 & 0.066 & 0.167 & 0.022 & 0.078 & 0.025 & 0.149 \\
\hline
\end{tabular}

Notes: The number of workers in small establishments is $>=10$ and $<150$. The number of workers in large establishments is $>=150$.

Table 2

JMP decomposition of the 90-50 and 50-10 log wage differentials among small and large establishments

\begin{tabular}{|c|c|c|c|c|c|c|c|c|}
\hline & \multicolumn{2}{|c|}{ Belgium } & \multicolumn{2}{|c|}{ Ireland } & \multicolumn{2}{|c|}{ Italy } & \multicolumn{2}{|c|}{ Spain } \\
\hline & 90-50 gap & 50-10 gap & 90-50 gap & 50-10 gap & 90-50 gap & 50-10 gap & 90-50 gap & 50-10 gap \\
\hline 1. Large & 0.563 & 0.418 & 0.822 & 0.581 & 0.513 & 0.447 & 0.612 & 0.715 \\
\hline 2. Large with $\beta_{\mathrm{S}}$ & 0.592 & 0.404 & 0.885 & 0.647 & 0.521 & 0.457 & 0.609 & 0.746 \\
\hline 3. Large with $\beta_{\mathrm{S}}$ and $\mathrm{X}_{\mathrm{S}}$ & 0.593 & 0.407 & 0.904 & 0.654 & 0.527 & 0.463 & 0.623 & 0.755 \\
\hline 4. Small & 0.587 & 0.331 & 0.768 & 0.623 & 0.582 & 0.330 & 0.764 & 0.465 \\
\hline 5. Large-Small (1-4) & -0.023 & 0.088 & 0.054 & -0.042 & -0.068 & 0.116 & -0.152 & 0.250 \\
\hline \multicolumn{9}{|l|}{ Effect of: } \\
\hline 6. Price $(1-2)$ & -0.028 & 0.014 & -0.063 & -0.066 & -0.008 & -0.010 & 0.003 & -0.032 \\
\hline 7. Residual (2-3) & -0.001 & -0.003 & -0.019 & -0.007 & -0.006 & -0.006 & -0.014 & -0.009 \\
\hline 8. Quantities (3-4) & 0.006 & 0.077 & 0.136 & 0.031 & -0.055 & 0.132 & -0.141 & 0.291 \\
\hline
\end{tabular}

Notes: The number of workers in small establishments is $>=10$ and $<150$. The number of workers in large establishments is $>=150$. 
Table 3

Between- and within-establishment components of wage dispersion

\begin{tabular}{lc|c|c|c} 
& \multicolumn{1}{c}{ Belgium } & Ireland & Italy & Spain \\
\cline { 2 - 5 } Employment share of small establishments $(\alpha)$ & 0.519 & 0.632 & 0.615 & 0.683 \\
Overall variance of log wages & 0.172 & 0.349 & 0.183 & 0.305 \\
Small establishments & & & & \\
Total variance of log wages & 0.165 & 0.324 & 0.154 & 0.271 \\
Between-establishment variance of log wages & 0.085 & 0.166 & 0.098 & 0.163 \\
Within-establishment variance of log wages & 0.080 & 0.158 & 0.056 & 0.108 \\
Mean log wages & 6.134 & 1.831 & 2.669 & 6.958 \\
Large establishments & 0.155 & 0.333 & 0.167 & 0.272 \\
Total variance of log wages & 0.072 & 0.154 & 0.090 & 0.156 \\
Between-establishment variance of log wages & 0.083 & 0.179 & 0.077 & 0.116 \\
Within-establishment variance of log wages & 6.358 & 2.116 & 3.003 & 7.345 \\
Mean log wages & & & & \\
Share of overall variance explained by : & 0.26 & 0.30 & 0.33 & 0.37 \\
$\alpha V_{B E}^{S}$ & 0.24 & 0.29 & 0.19 & 0.24 \\
$\alpha V_{W E}^{S}$ & 0.20 & 0.16 & 0.19 & 0.16 \\
$(1-\alpha) V_{B E}^{L}$ & 0.23 & 0.19 & 0.16 & 0.12 \\
$(1-\alpha) V_{W E}^{L}$ & 0.07 & 0.06 & 0.13 & 0.11 \\
$\alpha(1-\alpha)\left(\bar{W}^{S}-\bar{W}^{L}\right)^{2}$ &
\end{tabular}




\section{APPENDIX I}

Table Al

Means and standard deviations of selected variables

\begin{tabular}{|c|c|c|c|c|c|c|}
\hline & \multicolumn{3}{|c|}{ Belgium } & \multicolumn{3}{|c|}{ Ireland } \\
\hline & $\begin{array}{l}\text { Overall } \\
\text { Sample }\end{array}$ & $\begin{array}{c}\text { Small } \\
\text { Establ. }^{1}\end{array}$ & $\begin{array}{l}\text { Large } \\
\text { Establ. }^{2}\end{array}$ & $\begin{array}{l}\text { Overall } \\
\text { Sample }\end{array}$ & $\begin{array}{c}\text { Small } \\
\text { Establ. }\end{array}$ & $\begin{array}{c}\text { Large } \\
\text { Establ. }^{2}\end{array}$ \\
\hline $\begin{array}{l}\text { Gross hourly wage (in EUR) } \\
\text { Includes overtime paid, premiums for shift work, } \\
\text { night work and/or weekend work and bonuses (i.e. } \\
\text { irregular payments which do not occur during } \\
\text { each pay period, such as pay for holiday, } 13^{\text {th }} \\
\text { month, profit sharing, etc.). }\end{array}$ & $\begin{array}{l}14.04 \\
(7.37)\end{array}$ & $\begin{array}{l}12.54 \\
(6.8)\end{array}$ & $\begin{array}{l}15.57 \\
(7.6)\end{array}$ & $\begin{array}{l}11.51 \\
(9.2)\end{array}$ & $\begin{array}{l}9.56 \\
(8.2)\end{array}$ & $\begin{array}{l}12.67 \\
(9.6)\end{array}$ \\
\hline Education : & & & & & & \\
\hline No degree or primary & 12.3 & 11.97 & 12.48 & 6.26 & 7.68 & 5.40 \\
\hline Lower secondary & 22.5 & 21.67 & 23.39 & 22.26 & 24.42 & 20.99 \\
\hline Upper secondary (General/Techn/Artistic/Prof) & 40.6 & 42.91 & 38.34 & 50.47 & 51.39 & 49.93 \\
\hline Higher non-university, short type & 14.6 & 14.67 & 14.54 & 13.62 & 10.55 & 15.44 \\
\hline University and non-univ. higher educ., long type & 9.4 & 8.20 & 10.72 & 6.19 & 4.95 & 6.93 \\
\hline Post-graduate & 0.6 & 0.58 & 0.53 & 1.20 & 1.01 & 1.31 \\
\hline Prior potential experience (years) & 9.6 & 10.76 & 8.41 & 7.41 & 8.25 & 6.92 \\
\hline $\begin{array}{l}\text { Experience (potentially) accumulated on the } \\
\text { labour market before the last job. }\end{array}$ & $(8.3)$ & $(8.8)$ & $(7.5)$ & $(8.3)$ & $(8.8)$ & $(7.96)$ \\
\hline Seniority in the establishment (years) & $\begin{array}{l}10.4 \\
(9.5)\end{array}$ & $\begin{array}{l}8.44 \\
(8.7)\end{array}$ & $\begin{array}{l}12.42 \\
(9.8)\end{array}$ & $\begin{array}{c}9.23 \\
(8.86)\end{array}$ & $\begin{array}{l}7.89 \\
(7.9)\end{array}$ & $\begin{array}{l}10.03 \\
(9.2)\end{array}$ \\
\hline Blue-collar workers ${ }^{3}$ & 38.67 & 39.66 & 37.99 & 47.23 & 52.77 & 43.94 \\
\hline Female & 29.18 & 31.64 & 26.65 & 40.28 & 37.09 & 42.19 \\
\hline Overtime paid (yes) & 8.11 & 6.28 & 9.99 & 33.14 & 29.68 & 35.19 \\
\hline $\begin{array}{l}\text { Bonuses for shift work, night work and/or weekend } \\
\text { work (yes) } \\
\text { Type of contract: }\end{array}$ & 16.93 & 8.40 & 25.71 & - & - & - \\
\hline Unlimited-term employment contract & 96.73 & 97.56 & 95.86 & 93.75 & 93.99 & 93.79 \\
\hline Limited-term employment contract & 2.62 & 1.97 & 3.30 & 4.20 & 3.43 & 4.66 \\
\hline Apprentice/trainee contract or other contract & 0.65 & 0.47 & 0.84 & 2.05 & 2.88 & 1.55 \\
\hline Supervises the work of other workers (yes) & 16.34 & 16.47 & 16.20 & 9.25 & 9.27 & 9.23 \\
\hline Size of the establishment (number of workers) & $\begin{array}{c}671.71 \\
(1,528.2)\end{array}$ & $\begin{array}{c}51.94 \\
(38.45)\end{array}$ & $\begin{array}{l}1,309.49 \\
(1,983.6)\end{array}$ & $\begin{array}{c}1,631.1 \\
(2,986.1)\end{array}$ & $\begin{array}{c}68.83 \\
(37.49)\end{array}$ & $\begin{array}{c}2,556.5 \\
(3,449.1)\end{array}$ \\
\hline
\end{tabular}


Sector :

Other mining and quarrying

Manufacturing

Electricity, gas, steam and hot water supply

41.75

Construction

Wholesale and retail trade; repair of motor

vehicles, motorcycles and personal and household

goods

Hotels and restaurants

Transport, storage and communication

Financial intermediation

Real estate, renting and business activities

Level of wage bargaining :

National and/or sectoral CA

Above-enterprise CA

Enterprise CA

Establishment CA

Other pay-setting arrangements

Number of employees

Number of establishments

79,968

$\begin{array}{llllll}4,207 & 3,175 & 1,032 & 2,592 & 2,219\end{array}$

Notes: Standard deviations are reported between brackets. Descriptive statistics refer to the weighted sample.

1 Number of workers in the establishment $\geq 10$ and $<150$.

2 Number of workers in the establishment $\geq 150$.

3 Blue-collar workers are workers registered within ISCO codes 71 to 93. 
Table A1 (Cont.)

Means and standard deviations of selected variables

\begin{tabular}{|c|c|c|c|c|c|c|}
\hline & \multicolumn{3}{|c|}{ Italy } & \multicolumn{3}{|c|}{ Spain } \\
\hline & $\begin{array}{l}\text { Overall } \\
\text { Sample }\end{array}$ & $\begin{array}{c}\text { Small } \\
\text { Establ. }{ }^{1}\end{array}$ & $\begin{array}{l}\text { Large } \\
\text { Establ. }^{2}\end{array}$ & $\begin{array}{l}\text { Overall } \\
\text { Sample }\end{array}$ & $\begin{array}{c}\text { Small } \\
\text { Establ. }{ }^{1}\end{array}$ & $\begin{array}{c}\text { Large } \\
\text { Establ. }^{2}\end{array}$ \\
\hline $\begin{array}{l}\text { Gross hourly wage (in EUR) } \\
\text { Includes overtime paid, premiums for shift work, } \\
\text { night work and/or weekend work and bonuses (i.e. } \\
\text { irregular payments which do not occur during } \\
\text { each pay period, such as pay for holiday, } 13^{\text {th }} \\
\text { month, profit sharing, etc.). }\end{array}$ & $\begin{array}{l}17.88 \\
(9.6)\end{array}$ & $\begin{array}{l}15.73 \\
(8.0)\end{array}$ & $\begin{array}{l}22.06 \\
(10.9)\end{array}$ & $\begin{array}{l}8.65 \\
(6.1)\end{array}$ & $\begin{array}{l}7.39 \\
(5.4)\end{array}$ & $\begin{array}{l}10.7 \\
(6.6)\end{array}$ \\
\hline \multicolumn{7}{|l|}{ Education : } \\
\hline No degree or primary & 14.91 & 15.37 & 14.07 & 31.05 & 34.01 & 25.40 \\
\hline Lower secondary & 47.47 & 51.21 & 40.20 & 30.33 & 33.66 & 24.85 \\
\hline Upper secondary (General/Techn/Artistic/Prof) & 33.12 & 30.78 & 37.65 & 18.99 & 15.67 & 24.87 \\
\hline Higher non-university, short type & 0.35 & 0.23 & 0.57 & 8.46 & 6.73 & 11.51 \\
\hline University and non-univ. higher educ., long type & 4.12 & 2.40 & 7.45 & 11.09 & 9.86 & 13.28 \\
\hline Post-graduate & 0.03 & 0.01 & 0.06 & 0.08 & 0.07 & 0.09 \\
\hline $\begin{array}{l}\text { Prior potential experience (years) } \\
\text { Experience (potentially) accumulated on the } \\
\text { labour market before the last job. }\end{array}$ & $\begin{array}{l}11.85 \\
(9.7)\end{array}$ & $\begin{array}{l}12.54 \\
(10.3)\end{array}$ & $\begin{array}{l}10.51 \\
(8.2)\end{array}$ & $\begin{array}{c}12.82 \\
(9.7)\end{array}$ & $\begin{array}{l}14.26 \\
(10.2)\end{array}$ & $\begin{array}{c}10.29 \\
(7.9)\end{array}$ \\
\hline Seniority in the establishment (years) & $\begin{array}{l}10.09 \\
(8.8)\end{array}$ & $\begin{array}{l}8.31 \\
(7.7)\end{array}$ & $\begin{array}{l}13.55 \\
(9.7)\end{array}$ & $\begin{array}{l}10.53 \\
(9.9)\end{array}$ & $\begin{array}{c}8.53 \\
(9.02)\end{array}$ & $\begin{array}{l}14.06 \\
(10.4)\end{array}$ \\
\hline Blue-collar workers ${ }^{3}$ & 53.93 & 57.59 & 46.81 & 52.97 & 56.22 & 47.28 \\
\hline Female & 29.80 & 32.86 & 23.87 & 24.63 & 23.89 & 25.94 \\
\hline Overtime paid (yes) & 38.29 & 36.97 & 40.85 & 9.29 & 6.88 & 13.05 \\
\hline $\begin{array}{l}\text { Bonuses for shift work, night work and/or weekend } \\
\text { work (yes) }\end{array}$ & 20.06 & 13.76 & 32.30 & 14.13 & 7.02 & 26.70 \\
\hline Type of contract: & 93.8 & 92.96 & 95.43 & 73.06 & 66.81 & 84.13 \\
\hline Unlimited-term employment contract & 2.55 & 2.55 & 2.55 & 26.2 & 32.05 & 15.83 \\
\hline $\begin{array}{l}\text { Limited-term employment contract } \\
\text { Apprentice/trainee contract or other contract }\end{array}$ & 3.65 & 4.49 & 2.02 & 0.74 & 1.14 & 0.04 \\
\hline Supervises the work of other workers (yes) & 13.46 & 11.91 & 16.47 & - & - & - \\
\hline Size of the establishment (number of workers) & $\begin{array}{c}1,438.1 \\
(7,199.3)\end{array}$ & $\begin{array}{l}41.97 \\
(34.8)\end{array}$ & $\begin{array}{c}4,147.8 \\
(11,886)\end{array}$ & $\begin{array}{l}725.93 \\
(2,314)\end{array}$ & $\begin{array}{l}43.22 \\
(34.9)\end{array}$ & $\begin{array}{c}1,934.6 \\
(3,542.1)\end{array}$ \\
\hline \multicolumn{7}{|l|}{ Sector : } \\
\hline Other mining and quarrying & 0.45 & 0.50 & 0.36 & 0.39 & 0.52 & 0.16 \\
\hline
\end{tabular}




\begin{tabular}{lccc|ccc} 
Manufacturing & 50.56 & 51.54 & 48.68 & 38.79 & 37.33 & 41.47 \\
Electricity, gas, steam and hot water supply & 1.91 & 0.83 & 4.02 & 1.40 & 0.34 & 3.28 \\
Construction & 5.36 & 7.03 & 2.12 & 12.15 & 16.49 & 4.47 \\
Wholesale and retail trade; repair of motor & 8.72 & 11.46 & 3.29 & 19.08 & 21.74 & 14.22 \\
vehicles, motorcycles and personal and household & & & & & \\
goods & & & & & \\
Hotels and restaurants & 3.00 & 4.04 & 0.97 & 5.59 & 6.93 & 3.23 \\
Transport, storage and communication & 16.11 & 9.57 & 28.90 & 8.30 & 5.60 & 13.09 \\
Financial intermediation & 5.24 & 5.02 & 5.68 & 7.58 & 3.67 & 14.51 \\
Real estate, renting and business activities & 8.65 & 10.01 & 5.98 & 6.72 & 7.38 & 5.57 \\
National and/or sectoral CA & & & & & 35.0 & 31.2 \\
Above-enterprise CA & 75.7 & 83.6 & 60.2 & 33.7 & 3.0 & 18.5 \\
Enterprise CA & - & - & - & 38.0 & 49.1 & 11.6 \\
Establishment CA & 19.6 & 12.2 & 34.2 & 23.3 & 43.9 \\
Other pay-setting arrangements & 0.8 & 0.2 & 1.9 & 2.4 & 1.7 & 3.7 \\
Number of employees & 3.9 & 4.0 & 3.7 & 2.6 & 2.6 & 2.7 \\
\hline umber of establishments & 92,917 & 57,145 & 35,772 & 166,567 & 113,835 & 52,732 \\
\hline
\end{tabular}

Notes: Standard deviations are reported between brackets. Descriptive statistics refer to the weighted sample.

1 Number of workers in the establishment $\geq 10$ and $<150$.

2 Number of workers in the establishment $\geq 150$.

3 Blue-collar workers are workers registered within ISCO codes 71 to 93 . 


\section{APPENDIX II}

Table A2

Wage regressions for small and large establishments (Main variables) ${ }^{1}$

\begin{tabular}{|c|c|c|c|c|c|c|c|c|}
\hline & \multicolumn{2}{|c|}{ Belgium } & \multicolumn{2}{|c|}{ Ireland } & \multicolumn{2}{|c|}{ Italy } & \multicolumn{2}{|c|}{ Spain } \\
\hline & $\begin{array}{c}\text { Small } \\
\text { Establ. }^{2}\end{array}$ & $\begin{array}{c}\text { Large } \\
\text { Establ. }{ }^{3}\end{array}$ & $\begin{array}{l}\text { Small } \\
\text { Establ. }\end{array}$ & $\begin{array}{l}\text { Large } \\
\text { Establ. }\end{array}$ & $\begin{array}{l}\text { Small } \\
\text { Establ. }\end{array}$ & $\begin{array}{l}\text { Large } \\
\text { Establ. }\end{array}$ & $\begin{array}{l}\text { Small } \\
\text { Establ. }\end{array}$ & $\begin{array}{l}\text { Large } \\
\text { Establ. }\end{array}$ \\
\hline Education (reference: No degree or primary) & & & & & & & & \\
\hline Lower secondary & $\begin{array}{c}0.076^{* *} \\
(0.008)\end{array}$ & $\begin{array}{c}0.094 * * \\
(0.009)\end{array}$ & $\begin{array}{c}0.104 * * \\
(0.027)\end{array}$ & $\begin{array}{c}0.148 * * \\
(0.023)\end{array}$ & $\begin{array}{c}0.057 * * \\
(0.010)\end{array}$ & $\begin{array}{c}0.068 * * \\
(0.010)\end{array}$ & $\begin{array}{c}0.040 * * \\
(0.007)\end{array}$ & $\begin{array}{c}0.042 * * \\
(0.012)\end{array}$ \\
\hline Upper secondary (General/Techn/Artistic/Prof) & $\begin{array}{c}0.171 * * \\
(0.010)\end{array}$ & $\begin{array}{c}0.200 * * \\
(0.010)\end{array}$ & $\begin{array}{c}0.229 * * \\
(0.027)\end{array}$ & $\begin{array}{c}0.239 * * \\
(0.024)\end{array}$ & $\begin{array}{c}0.130^{* *} \\
(0.013)\end{array}$ & $\begin{array}{c}0.169 * * \\
(0.013)\end{array}$ & $\begin{array}{c}0.152 * * \\
(0.009)\end{array}$ & $\begin{array}{c}0.174 * * \\
(0.014)\end{array}$ \\
\hline Higher non-university, short type & $\begin{array}{c}0.237 * * \\
(0.011)\end{array}$ & $\begin{array}{c}0.275^{* *} \\
(0.013)\end{array}$ & $\begin{array}{c}0.351 * * \\
(0.027)\end{array}$ & $\begin{array}{c}0.333 * * \\
(0.029)\end{array}$ & $\begin{array}{c}0.070 * * \\
(0.041)\end{array}$ & $\begin{array}{c}0.154 * * \\
(0.044)\end{array}$ & $\begin{array}{c}0.115^{* *} \\
(0.009)\end{array}$ & $\begin{array}{c}0.163 * * \\
(0.016)\end{array}$ \\
\hline University and non-univ. higher educ., long type & $\begin{array}{c}0.401 * * \\
(0.015)\end{array}$ & $\begin{array}{c}0.481 * * \\
(0.019)\end{array}$ & $\begin{array}{c}0.564 * * \\
(0.035)\end{array}$ & $\begin{array}{c}0.519 * * \\
(0.035)\end{array}$ & $\begin{array}{c}0.163 * * \\
(0.024)\end{array}$ & $\begin{array}{c}0.232 * * \\
(0.022)\end{array}$ & $\begin{array}{c}0.316^{* *} \\
(0.012)\end{array}$ & $\begin{array}{c}0.326^{* *} \\
(0.019)\end{array}$ \\
\hline Post-graduate & $\begin{array}{c}0.526^{* *} \\
(0.043)\end{array}$ & $\begin{array}{c}0.602 * * \\
(0.037)\end{array}$ & $\begin{array}{c}0.715 * * \\
(0.053)\end{array}$ & $\begin{array}{c}0.693 * * \\
(0.055)\end{array}$ & $\begin{array}{c}0.242 * * \\
(0.095)\end{array}$ & $\begin{array}{c}0.543 * * \\
(0.056)\end{array}$ & $\begin{array}{c}0.507 * * \\
(0.096)\end{array}$ & $\begin{array}{c}0.504 * * \\
(0.057)\end{array}$ \\
\hline $\begin{array}{l}\text { Prior potential experience (years) } \\
\text { Experience (potentially) accumulated on the labour market before } \\
\text { the last job }\end{array}$ & $\begin{array}{c}0.020 * * \\
(0.002)\end{array}$ & $\begin{array}{c}0.017 * * \\
(0.001)\end{array}$ & $\begin{array}{c}0.034 * * \\
(0.002)\end{array}$ & $\begin{array}{c}0.032 * * \\
(0.005)\end{array}$ & $\begin{array}{c}0.011 * * \\
(0.002)\end{array}$ & $\begin{array}{c}0.011 * * \\
(0.002)\end{array}$ & $\begin{array}{c}0.025 * * \\
(0.001)\end{array}$ & $\begin{array}{c}0.025^{* *} \\
(0.001)\end{array}$ \\
\hline Seniority in the establishment (years) & $\begin{array}{c}0.020 * * \\
(0.001)\end{array}$ & $\begin{array}{c}0.020 * * \\
(0.001)\end{array}$ & $\begin{array}{c}0.038 * * \\
(0.002)\end{array}$ & $\begin{array}{c}0.045 * * \\
(0.004)\end{array}$ & $\begin{array}{c}0.016 * * \\
(0.001)\end{array}$ & $\begin{array}{c}0.016 * * \\
(0.001)\end{array}$ & $\begin{array}{c}0.026^{* *} \\
(0.001)\end{array}$ & $\begin{array}{c}0.023^{* *} \\
(0.001)\end{array}$ \\
\hline Female & $\begin{array}{c}-0.099 * * \\
(0.005)\end{array}$ & $\begin{array}{c}-0.115^{* *} \\
(0.007)\end{array}$ & $\begin{array}{c}-0.226^{* *} \\
(0.010)\end{array}$ & $\begin{array}{c}-0.181 * * \\
(0.018)\end{array}$ & $\begin{array}{c}-0.129 * * \\
(0.008)\end{array}$ & $\begin{array}{c}-0.101 * * \\
(0.008)\end{array}$ & $\begin{array}{c}-0.186^{* * *} \\
(0.008)\end{array}$ & $\begin{array}{c}-0.179 * * \\
(0.008)\end{array}$ \\
\hline Overtime paid (yes) & $\begin{array}{l}0.023^{*} \\
(0.010)\end{array}$ & $\begin{array}{l}-0.001 \\
(0.001)\end{array}$ & $\begin{array}{l}0.058^{*} \\
(0.011)\end{array}$ & $\begin{array}{c}-0.041^{*} \\
(0.016)\end{array}$ & $\begin{array}{c}0.042 * * \\
(0.008)\end{array}$ & $\begin{array}{l}-0.007 \\
(0.007)\end{array}$ & $\begin{array}{c}0.134 * * \\
(0.009)\end{array}$ & $\begin{array}{c}0.128 * * \\
(0.001)\end{array}$ \\
\hline Bonuses for shift work, night work and/or weekend work (yes) & $\begin{array}{c}0.053 * * \\
(0.009)\end{array}$ & $\begin{array}{c}0.066 * * \\
(0.011)\end{array}$ & - & - & $\begin{array}{c}0.102 * * \\
(0.012)\end{array}$ & $\begin{array}{c}0.048 * * \\
(0.008)\end{array}$ & $\begin{array}{c}0.089 * * \\
(0.009)\end{array}$ & $\begin{array}{c}0.050 * * \\
(0.011)\end{array}$ \\
\hline Type of contract (reference: Unlimited-term employment contract) & & & & & & & & \\
\hline Limited-term employment contract & $\begin{array}{c}-0.081 * * \\
(0.026)\end{array}$ & $\begin{array}{c}-0.088 * * \\
(0.017)\end{array}$ & $\begin{array}{c}-0.063 * \\
(0.026)\end{array}$ & $\begin{array}{c}-0.075^{*} \\
(0.029)\end{array}$ & $\begin{array}{c}-0.054 * * \\
(0.017)\end{array}$ & $\begin{array}{c}-0.095^{* *} \\
(0.020)\end{array}$ & $\begin{array}{c}-0.105^{* *} \\
(0.009)\end{array}$ & $\begin{array}{c}-0.199 * * \\
(0.013)\end{array}$ \\
\hline Apprentice/trainee contract or other contract & $\begin{array}{c}-0.348 * * \\
(0.067)\end{array}$ & $\begin{array}{c}-0.040 * * \\
(0.081)\end{array}$ & $\begin{array}{c}-0.230 * * \\
(0.022)\end{array}$ & $\begin{array}{c}-0.184 * * \\
(0.049)\end{array}$ & $\begin{array}{c}-0.161 * * \\
(0.021)\end{array}$ & $\begin{array}{c}-0.168^{* *} \\
(0.022)\end{array}$ & $\begin{array}{c}-0.448 * * \\
(0.042)\end{array}$ & $\begin{array}{c}-0.436^{* *} \\
(0.074)\end{array}$ \\
\hline Supervises the work of other workers (yes) & $\begin{array}{c}0.121 * * \\
(0.007)\end{array}$ & $\begin{array}{c}0.139 * * \\
(0.009)\end{array}$ & $\begin{array}{c}0.162 * * \\
(0.011)\end{array}$ & $\begin{array}{c}0.127 * * \\
(0.017)\end{array}$ & $\begin{array}{c}0.161 * * \\
(0.012)\end{array}$ & $\begin{array}{c}0.138 * * \\
(0.011)\end{array}$ & - & - \\
\hline Size of the establishment (number of workers) & $0.022 * *$ & $0.040 * *$ & $0.100 * *$ & 0.009 & $0.049 * *$ & $0.017 * *$ & $0.062 * *$ & 0.011 \\
\hline
\end{tabular}


Level of wage bargaining (reference: National and/sectoral CA) Above-enterprise CA

\section{Enterprise CA}

Establishment CA

Other pay-setting arrangements

Mean years of experience per establishment

Mean years of seniority per establishment

Share of highly educated workers per establishment

Number of employees

Number of establishments

Adj.R ${ }^{2}$

F-stat

\begin{tabular}{|c|c|c|c|c|c|c|c|}
\hline$(0.004)$ & $(0.007)$ & $(0.012)$ & $(0.013)$ & $(0.006)$ & $(0.006)$ & $(0.005)$ & $(0.007)$ \\
\hline- & - & - & - & - & - & $\begin{array}{c}0.020 * * \\
(0.007)\end{array}$ & $\begin{array}{c}-0.003 \\
(0.015)\end{array}$ \\
\hline $0.016^{\circ}$ & 0.006 & & & $0.049 *$ & $-0.035^{*}$ & $0.070 * *$ & $0.072 * *$ \\
\hline (0.009) & $(0.010)$ & & & $(0.011)$ & $(0.012)$ & $(0.014)$ & $(0.019)$ \\
\hline- & - & $\begin{array}{c}-0.045^{*} \\
(0.018)\end{array}$ & $\begin{array}{c}0.010 \\
(0.030)\end{array}$ & $\begin{array}{l}0.003 * \\
(0.031)\end{array}$ & $\begin{array}{l}0.061^{*} \\
(0.029)\end{array}$ & $\begin{array}{c}0.079 * * \\
(0.027)\end{array}$ & $\begin{array}{c}0.093 * * \\
(0.023)\end{array}$ \\
\hline $\begin{array}{c}-0.037 * * \\
(0.012)\end{array}$ & $\begin{array}{c}0.026 \\
(0.027)\end{array}$ & - & - & $\begin{array}{c}-0.079 * * \\
(0.019)\end{array}$ & $\begin{array}{c}0.037 \\
(0.038)\end{array}$ & $\begin{array}{c}0.017 \\
(0.024)\end{array}$ & $\begin{array}{c}0.021 \\
(0.032)\end{array}$ \\
\hline $0.002 *$ & $0.007 * *$ & $0.004 *$ & $0.010^{*}$ & 0.001 & $-0.005^{* *}$ & $0.002 *$ & $0.011 *$ \\
\hline$(0.001)$ & $(0.002)$ & $(0.002)$ & $(0.004)$ & $(0.001)$ & $(0.001)$ & $(0.001)$ & $(0.002)$ \\
\hline $0.004 * *$ & $0.005 * *$ & $0.008 * *$ & $0.014 * *$ & 0.001 & 0.001 & $0.002 *$ & $0.007^{*}$ \\
\hline$(0.001)$ & $(0.001)$ & $(0.002)$ & $(0.004)$ & $(0.001)$ & $(0.001)$ & $(0.001)$ & $(0.001)$ \\
\hline $0.157 * *$ & $0.167 * *$ & $0.213 * *$ & $0.199 *$ & $0.122^{\circ}$ & $0.074^{\circ}$ & $0.276^{* *}$ & $0.398 * *$ \\
\hline$(0.016)$ & $(0.029)$ & $(0.057)$ & $(0.081)$ & $(0.067)$ & $(0.043)$ & $(0.018)$ & $(0.036)$ \\
\hline 41,547 & 38,421 & 23,061 & 13,430 & 57,145 & 35,772 & 113,835 & 52,732 \\
\hline 3,175 & 1,032 & 2,219 & 373 & 5,625 & 2,040 & 15,116 & 2,472 \\
\hline 0.67 & 0.70 & 0.60 & 0.67 & 0.64 & 0.72 & 0.57 & 0.62 \\
\hline $572.02 * *$ & $788.81^{* *}$ & $302.14^{* *}$ & $299.64 * *$ & $323.65^{* *}$ & $225.16^{* *}$ & $415.52 * *$ & $194.36^{* *}$ \\
\hline
\end{tabular}

Notes: The dependent variable is the ln of individual gross hourly wages including annual bonuses (i.e. irregular payments which do not occur during each pay period, such as pay for holiday, $13^{\text {th }}$ month and profit sharing).

$* * / * / \circ$ : statistically significant at the 1,5 and $10 \%$ level, respectively. Standard errors, reported between brackets, are corrected for heteroscedasticity and for the clustered sampling scheme.

1 The variables which do not appear in this table but that have been included in our wage regressions are: prior potential experience (in squared and cubed), tenure (in squared), occupation (19 dummies), ln of paid hours, region where the establishment is located (Belgium: 2 dummies, Ireland: none, Italy: 10 dummies, and Spain: 6 dummies), establishment's economic and financial control (Belgium: 3 dummies, Ireland: 2 dummies, Italy: none, and Spain: 3 dummies), sectoral affiliation (Belgium and Italy: 41 dummies, Ireland: 33 dummies, Spain: 8 dummies).

2 Number of workers in the establishment $\geq 10$ and $<150$.

3 Number of workers in the establishment $\geq 150$. 


\section{APPENDIX III}

Table A3

Correlation between price or residual effects on the variance of log wages and four collective bargaining characteristics

\begin{tabular}{|c|c|c|c|c|c|c|c|}
\hline & Year & Price effect & Residual effect & $\begin{array}{c}\text { Degree of } \\
\text { centralisation }^{1}\end{array}$ & $\begin{array}{c}\text { Degree of } \\
\text { coordination }^{2}\end{array}$ & $\begin{array}{c}\text { Union coverage } \\
\text { rate }^{3}\end{array}$ & Union density $^{4}$ \\
\hline Belgium & 1995 & 0.010 & 0.009 & 10 & 2 & 0.96 & 0.51 \\
\hline Ireland & 1995 & 0.037 & 0.019 & 6 & 1 & 0.66 & 0.5 \\
\hline Spain & 1995 & 0.012 & 0.011 & 7 & 2 & 0.83 & 0.11 \\
\hline
\end{tabular}

Pearson coefficient of correlation between price or residual effects and two collective bargaining characteristics:
(1) Price
$-0.07$
$-0.94 *$
$-0.89^{\circ 0}$
0.30
$0.97 *$
0.26

(2) Residual

$-0.32$

$-0.98^{*}$

Notes: $*^{* / 0} /{ }^{\circ}$ : Statistically significant at the 5, 10 and $15 \%$ level, respectively. ${ }^{1}$ Nickell and Layard (1999). The scale ranges between 1 and 17. A large value is associated with a highly centralised country. ${ }^{2}$ Nickell and Layard (1999). Average of union and employer coordination. 1, 2 and 3 stand for low, intermediate and high coordination, respectively. ${ }^{3}$ EIRO (2002) and Traxler et al. (2001). ${ }^{4}$ Nickell and Layard (1999).

Table A3(Cont.)

Correlation between price or residual effects on 90-10 log wage differential and four collective bargaining characteristics

\begin{tabular}{|c|c|c|c|c|c|c|c|}
\hline & Year & Price effect & Residual effect & $\begin{array}{c}\text { Degree of } \\
\text { centralisation }^{1}\end{array}$ & $\begin{array}{c}\text { Degree of } \\
\text { coordination }^{2} \\
\end{array}$ & $\begin{array}{c}\text { Union coverage } \\
\text { rate }^{3} \\
\end{array}$ & Union density $^{4}$ \\
\hline Belgium & 1995 & 0.014 & 0.005 & 10 & 2 & 0.96 & 0.51 \\
\hline Ireland & 1995 & 0.129 & 0.025 & 6 & 1 & 0.66 & 0.5 \\
\hline Italy & 1995 & 0.018 & 0.013 & 5 & 2 & 0.90 & 0.39 \\
\hline Spain & 1995 & 0.029 & 0.023 & 7 & 2 & 0.83 & 0.11 \\
\hline \multicolumn{8}{|c|}{ Pearson coefficient of correlation between price or residual effects and two collective bargaining characteristics: } \\
\hline (1) Price & & & & -0.35 & $-0.99 *$ & $-0.95^{*}$ & 0.33 \\
\hline (2) Residual & & & & -0.60 & -0.61 & $-0.88^{\circ 0}$ & -0.44 \\
\hline
\end{tabular}

